\title{
Ocorrência de Sclerotium rolfsii em Rumex acetosa no Paraná
}

\author{
Gilmar Franzener ${ }^{1}$, Gabriela Silva Moura ${ }^{2}$, Cristiane Cláudia Meinerz ${ }^{3}$ \& José Renato Stangarlin ${ }^{3}$
}

${ }^{1}$ Universidade Federal da Fronteira Sul (UFFS), Av. Oscar da Silva Guedes, 01, CEP 85303-775, Laranjeiras do Sul, PR; ${ }^{2}$ Universidade Estadual de Maringá (UEM), Av. Colombo, 5790, CEP 87020-200, Maringá, PR; ${ }^{3}$ Universidade Estadual do Oeste do Paraná (UNIOESTE), Rua Pernambuco, 1777, Cx. P. 91, CEP 85960-000, Marechal Cândido Rondon, PR.

Autor para correspondência: Gilmar Franzener (gilmar.franzener@uffs.edu.br)

Data de chegada: 15/02/2013. Aceito para publicação em: 22/03/2013.
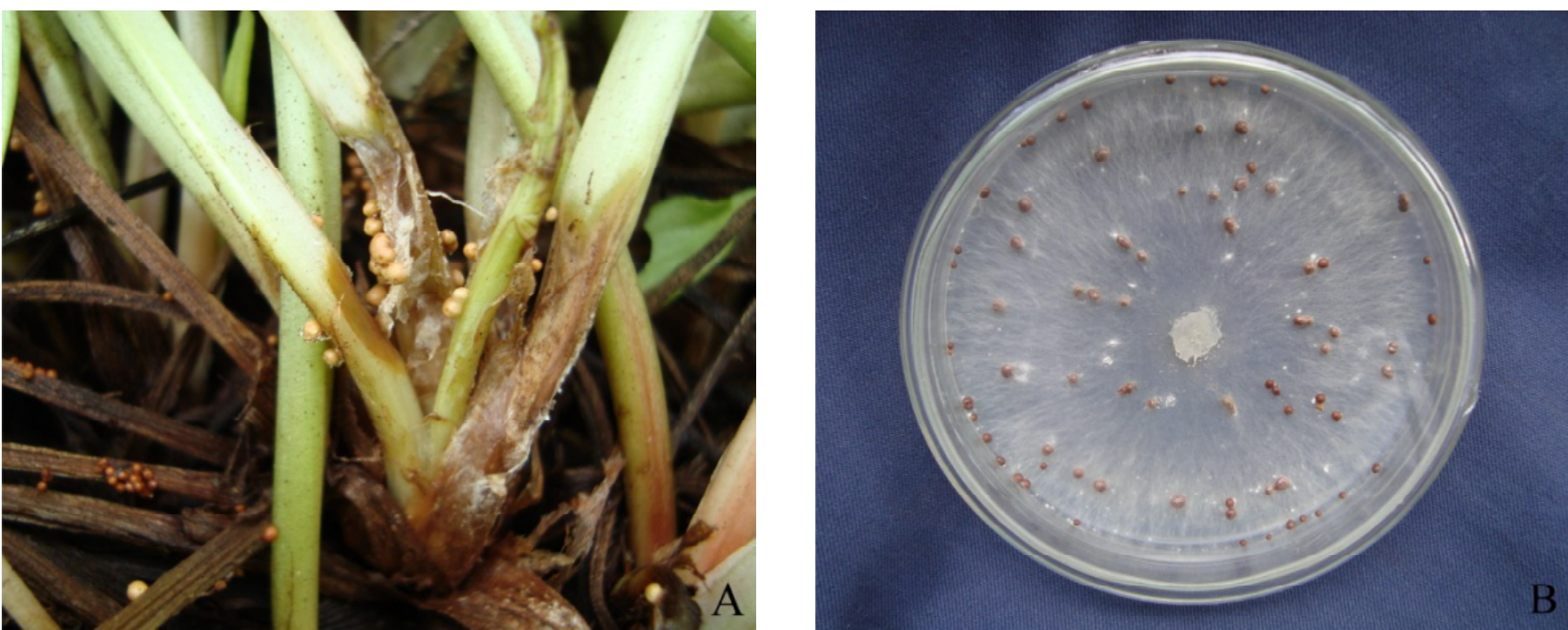

Figura 1. Sintomas e sinais da podridão de colo causada por Sclerotium rolfsii em Rumex acetosa, mostrando presença de micélio, formação de escleródios e necrose do colo, bainha e pecíolos (A); Micélio e formação de escleródios em meio BDA (B).

Rumex acetosa L. é uma hortaliça herbácea geralmente conhecida pelo nome comum de azedinha-da-horta, ou apenas azedinha. Embora seja uma cultura pouco conhecida em grandes centros, é uma planta muito cultivada e consumida no interior, sendo muito comum a presença de algumas plantas em hortas familiares. $R$. acetosa pertence a família Polygonaceae e apresenta folhas verdes arredondadas, com consistência que lembra agrião. Nos últimos anos essa planta tem merecido maior atenção por suas propriedades nutricionais e medicinais. Alguns trabalhos mostraram que as folhas e, principalmente, raízes, são importantes fontes do anti-oxidante resveratrol. Nos meses de abril e maio de 2009, plantas de $R$. acetosa cultivadas em hortas na região oeste do estado do Paraná passaram a apresentar sintomas de murcha, estrangulamento na região do colo, bainha e pecíolos, acompanhado de amarelecimento e morte de folhas mais velhas. Ainda no campo foram observados na área lesionada sinais do patógeno representados por micélio branco e produção de escleródios (Figura 1A). O patógeno foi isolado em meio de cultivo BDA (Figura 1B) e identificado como Sclerotium rolfsii Sacc. Para tanto, foram tomados por base os caracteres morfológicos descritos para espécie, como escleródios arredondados de 0,5 a $1,5 \mathrm{~mm}$ de diâmetro, inicialmente claros, tornando-se marrom escuros, e micélio cotonoso de cor branca com células de 150 a $250 \mu \mathrm{m}$ de comprimento por 2 a $9 \mu \mathrm{m}$ de largura. Esse fungo já foi relatado em diversas espécies de plantas, incluindo dicotiledôneas, principalmente fabáceas e solanáceas, e monocotiledôneas. Para realizar o teste de patogenicidade foram preparadas mudas sadias cultivadas em vasos contendo solo esterilizado por autoclavagem. A inoculação foi realizada depositando-se junto ao colo de cada planta três discos de BDA contendo micélio e escleródios do fungo. Plantas testemunhas receberam discos contendo apenas BDA. Foram utilizadas 10 plantas inoculadas com o patógeno e 10 plantas testemunhas. Após a inoculação, as plantas foram mantidas em câmara úmida por 48 horas. Cinco dias após a inoculação foram observados sinais do patógeno no colo, bainhas e base dos pecíolos das plantas, com posterior estrangulamento na área afetada. Todas as plantas inoculadas com o patógeno manifestaram os sintomas. A partir de pecíolos lesionados foi realizado o re-isolamento do patógeno para completar os postulados de Koch. Este é o primeiro relato de $S$. rolfsii atacando plantas de $R$. acetosa no estado do Paraná, e, aparentemente, no Brasil. 